\title{
PERUBAHAN PERILAKU MALADAPTIF DENGAN JADWAL TERSTRUKTUR PADA ANAK AUTISME
}

\author{
Suprihatin \& Siti Nuraini Purnamawati \\ e-mail: kehoksuprihatin@yahoo.com \\ Jurusan Pendidikan Luar Biasa, FIP Universitas Negeri Jakarta
}

\begin{abstract}
Abstrak: Penelitian ini bertujuan untuk mengetahui ada atau tidaknya perubahan perilaku maladaptif subjek yaitu perilaku menolehkan kepalanya ke arah jendela, meninggalkan tempat duduk untuk mencari lebah dan mengejar lebah selama pembelajaran berlangsung setelah anak diberikan perlakuan menggunakan jadwal terstruktur yang sesuai dengan ciri khas tujuan perilaku maladaptifnya. Penelitian ini dilakukan di SLB Tegar Harapan di Sleman DIY bulan Juni sampai dengan November 2012. Subjek penelitian ini adalah seorang siswa autisme yang terus-menerus memunculkan perilaku maladaptif yang sudah disebutkan, sehingga kurang fokus pada pembelajaran yang sedang berlangsung. Penelitian ini menggunakan metode Penelitian Studi Kasus dengan menggunakan Subjek Tunggal dengan desain ABA yang datanya dikumpulkan dengan metode observasi. Data yang diperoleh dianalisis dengan menggunakan analisis data sederhana. Berdasarkan penelitian yang telah dilakukan, pada umumnya frekuensi perilaku maladaptif yang dimunculkan oleh subjek menunjukkan kecenderungan yang berkurang sampai dengan 1 . Penggunaan metode ini perlu diterapkan kepada berbagai siswa autisme yang memiliki kekakuan kebiasaan yang berbeda lainnya sehingga akan dapat ditemukan efektivitas penelitian ini pada populasi yang lebih banyak.
\end{abstract}

Kata kunci : anak autisme, kekakuan kebiasaan, perilaku maladaptif, jadwal terstruktur

\section{MALADAPTIVE BAHAVIOR CHANGE WITH STRUCTURED SCHEDULE ON AUTISTIC CHILD}

\begin{abstract}
Abstrak: This research aimed at discovering the maladaptive bevavior change of the subject that is turning his/her head towards the window, leaving the seat to search the bee during the lesson after the child had been given the treatment using a structured schedule which fit to the peculiar characteristics of his/her maladaptive behavior objective. The research was conducted at SLB Tegar Harapan in Sleman (IY) as from June through Novemebr 2012. The research subject was an autistic child continuaously showing maladaptive behavior as mentioned before that made him not concentrate to rthe lesson. As a Single Subject Research with ABA design, this research applied obervation method to collect the data to be analyzed with simple technique. The findings showed in general the frequency of maladaptive behavior showed by the subject tent to decrease up to 1. Based on the findings, the research suggested to implement this method for other autistic children/more population to prove the effectiveness of the method.
\end{abstract}

Keywords: autistic child, maladaptive behavior, structured schedule.

\section{PENDAHULUAN}

Education for all merupakan semboyan baru dalam dunia pendidikan yang mengandung arti bahwa pada dasarnya pendidikan harus dapat dinikmati oleh semua termasuk mereka yang memiliki kebutuhan pendidikan khusus. Pelayanan pendidikan di Indonesia pada umumnya sudah mulai berubah menuju ke arah perbaikan dalam segala hal, seperti perubahan sikap dan penerimaan, penggunaan metodemetode baru dalam pelayanan, serta paradigma yang berproses menuju kepada pendidikan kemanusiaan. Demikian juga dengan pelayanan pendidikan bagi anak autisme, sedang mengalami perubahan menuju kepada pendidikan yang lebih baik dan manusiawi.

Salah satu permasalahan yang masih sering dihadapi oleh para guru untuk anak autis adalah perilaku anak yang maladaptif, sehingga terlihat kurang memperhatikan pelajaran. Anak biasanya akan cenderung mencurahkan perhatiannya kepada hal-hal yang sangat disenanginya dan menarik bagi mereka. Dalam kasus disini, khususnya anak autisme akan terus menerus melihat keluar jendela karena dia sangat menggemari gerakan-gerakan yang dibuat oleh lebah. Kalau mereka belajar, biasanya mereka akan sering melihat ke arah jendela dan mengeluarkan badan dari 
tempat duduknya. Tingkah laku seperti ini sangat mengganggu bagi temannya yang lain, sehingga hal ini akan membuyarkan konsentrasi semua anak dalam satu kelas dan guru. Jika hal ini terjadi, maka pelajaran akan kurang berhasil.

Dalam kenyataan kehidupan sehari-hari, kita tidak selalu selamanya harus sesuai seperti kemauan kita. Kita juga harus belajar bertoleransi bahwa perilaku kita juga akan mengganggu teman yang lain yang sedang belajar. Ada kalanya orang lain bisa mengerti mengapa seseorang harus bertingkah laku aneh, tetapi ada kalanya juga orang lain tidak mau mengerti. Dalam kehidupan anak autis, hal-hal seperti ini tidak terjadi dengan sendirinya. Mereka harus diajarkan sebab akibat, walaupun bagi orang lain hal tersebut mudah, namun bagi anak autis perlu dipelajari. Permasalahan seperti ini dikarenakan kelainan yang terjadi akibat autisme yang disandangnya, sehingga mengakibatkan terjadinya rigidity or inflexibility of thinking and behaviour (Wing, 1974).

Mengajar anak berkebutuhan khusus tidak semudah mengajar anak yang tidak membutuhkan perlakuan khusus. Lebih khusus lagi ketika kita mengajar anak autis, guru dituntut untuk menemukan jalan keluar yang berguna untuk memudahkan proses pembelajaran. Salah satu metode yang bisa digunakan untuk mengubah pola perilaku anak autis adalah jadwal terstruktur, (TEACCH, 2006). Melalui penelitian ini, guru diharapkan mampu menggunakan jadwal terstruktur baik di lingkungan sekolah maupun di luar sekolah dalam upaya mengatasi kekakuan kebiasaan yang seringkali terjadi pada penyandang autis.

Berdasarkan latar belakang yang telah diuraikan, maka dilakukan penelitian dengan menggunakan jadwal terstruktur yang dibuat secara khusus dan disesuaikan dengan minat dan ketertarikan siswa dengan tujuan untuk mengurangi perilaku maladaptif yang sering dimunculkan oleh siswa ketika pembelajaran sedang berlangsung. Perilaku maladaptif tersebut antara lain melihat ke arah jendela, meninggalkan tempat duduk, dan mengejar lebah.

\section{Kajian Teori}

Kata 'autis' diperkenalkan pertama kali pada tahun 1943 oleh Leo Kanner, seorang ahli ilmu jiwa anak-anak, dalam tulisannya yang mendeskripsikan tentang 11 pasiennya di Universitas John Hopkins, Amerika Serikat (Mesibov \& Howley, 2003). Anakanak tersebut memiliki sedikit ketertarikan kepada orang lain, berbahasa secara aneh, rutinitas yang sama, dan menunjukkan gerakan anggota badan yang berbeda dari anak yang lain, dan mengulang tingkah laku yang sama.
Kanner menerangkan bahwa 11 pasien yang digambarkan dalam laporannya meng-alami kesulitan pada tiga area utama, yaitu sosial, komunikasi, dan pemikiran. Perkembangan selanjutnya, ketiga aspek utama dalam autisme disebut sebagai triad of impairments dan memunculkan istilah 'Autism Spectrum Disorders' (Wing dalam Volkmar, et.al., 2005) atau dalam Bahasa Indonesia disebut sebagai Gangguan Spektrum Autisme (Ginanjar, 2007). Istilah Autism Spectrum Disorders lebih banyak digunakan dari pada istilah yang digunakan pada awal kemunculan autisme, yaitu Pervasive Developmental Disorders.

Seperti tersirat pada nama yang dimilikinya, gangguan spektrum autisme (GSA), memiliki berbagai macam subtipe. Gangguan ini ditemukan dari mulai yang paling berat yang berarti memiliki tanda-tanda atau karakteristik autistik sangat banyak sampai yang paling ringan dengan karakteristik yang hampir tidak bisa dilihat sama sekali. Tipe-tipe tersebut adalah (1) Pervasive Developmental Disorders-Not Otherwise Specified (PDD-NOS) atau Atypical Autism, (2) Asperger's disorder atau Asperger Syndrome, (3) Childhood Disintegrative Disorder, Rett's disorder atau Rett Syndrome, dan (4) Autistic disorder atau Childhood autism (Volkmar \& Klin, 2005). GSA bukanlah suatu penyakit, sehingga belum ada obat yang bisa digunakan untuk menyembuhkan gangguan yang ditimbulkan. GSA akan menetap pada penyandangnya selama mereka hidup dan karakteristiknya bisa diminimalisir bahkan dihilangkan dengan pemberian perlakuan tertentu.

Menurut Rimland dalam Ginanjar, autisme adalah gangguan yang disebabkan oleh kesalahan pada syaraf otak (Ginanjar, 2007). Menurut penelitian terbaru, autisme lebih banyak disebabkan karena faktor gen si penyandangnya. Autisme bisa mengenai siapa saja, baik sosio-ekonomi mapan maupun kurang, yang dimulai dari masa kanak-kanak yang menetap hingga dewasa dan semua etnis. Autisme tidaklah disebabkan oleh vaksinasi MMR yang selama ini masih dipercayai oleh sebagian orang, sehingga vaksinasi MMR tidak perlu dihindari (Fitzpatrick, 2004).

Autism Spectrum Disorders atau Gangguan Spektrum Autisme (GSA) merupakan suatu gangguan perkembangan yang kompleks yang muncul pada masa awal perkembangan anak dan ditandai dengan adanya gangguan pada tiga aspek utama, yaitu sosial, komunikasi, dan tingkah laku. GSA akan menetap pada anak sampai mereka dewasa yang gejalanya bisa terkurangi dengan memberikan berbagai macam perlakuan yang konsisten kepada anak.

Seorang individu dikatakan mengalami atau menyandang atau memiliki autisme, jika mereka 
mempunyai gangguan dalam tiga area utama yang biasa disebut dengan triads of impairment, yaitu bahasa dan komunikasi, sosialisasi dan tingkah laku. Bahasa dan komunikasi merupakan salah satu karakteristik dari individu dengan autisme. Setiap individu dengan autisme bisa dipastikan, bahwa mereka memiliki permasalahan dengan keterampilan dan kemampuan berbahasa dan berkomunikasi. Masingmasing individu dengan autisme memiliki gaya atau cara berkomunikasi yang berbeda-beda. Ada yang berkomunikasi dengan bahasa lisan, dengan gerakan tubuh, dan dengan menggunakan alat-alat bantu yang bisa diajarkan pada masing-masing individu. Kemampuan berkomunikasi ini menunjukkan jenis atau tipe autisme yang mereka miliki.

Keterampilan sosial yang dimiliki oleh individu dengan autisme kemungkinan adalah kemampuan yang paling bermasalah diantara triad of impairments. Individu dengan autisme tidak bisa belajar hal-hal yang berhubungan dengan sosial secara otomatis karena segala hal yang ada dalam kategori sosial cenderung abstrak. Hal-hal yang abstrak inilah yang sebenarnya sangat sulit untuk dicerna oleh individu dengan autisme. Mereka jarang sekali mempunyai teman, yang mereka punya hanyalah kenalan. Hal ini disebabkan karena mereka kurang mampu mengerti makna pertemanan, menjaga, serta memupuk hubungan pertemanan, sehingga seringkali mereka terlihat lebih suka menyendiri dan asyik dengan dunianya sendiri.

Hal yang paling bermasalah berikutnya pada orang-orang dengan autisme adalah cara berpikir mereka yang kurang fleksibel atau kaku. Mereka tidak mempunyai kemampuan untuk memprediksi hal-hal apa yang mungkin atau akan terjadi, setelah kegiatan atau perilaku dimunculkan dan diselesaikan. Oleh karena itu, mereka cenderung mengulang perbuatan yang sama setiap saat, sehingga kelihatan seperti kegiatan yang membosankan.

Orang lain yang melihat kegiatan individu dengan autisme yang diulang-ulang mungkin memang membosankan. Contoh kegiatan yang diulang-ulang tersebut adalah seorang anak yang cenderung ingin melihat satu film yang sama setiap hari. Dia tidak pernah mau melihat film dengan judul dan cerita lain. Contoh lainnya, individu yang cenderung ingin melewati jalan tertentu atau yang sama saja setiap hari, misalnya untuk pergi dan pulang sekolah. Kegiatankegiatan ini jika diubah atau diusahakan untuk diubah oleh orang lain, maka akan membuat individu bereaksi secara berbeda. Reaksi yang dikeluarkan mulai dari yang paling menakutkan, seperti tantrum atau me- ngamuk, menyakiti diri sendiri sampai dengan yang paling bisa diterima, seperti mengomel. Individu dengan autisme sendiri yang bisa menyikapi perubahan secara santai akan terlihat panik, khawatir, dan bingung secara jelas pada perubahan wajahnya. Namun, ketika perubahan akan dilakukan dan diberitahukan sebelumnya kepada anak, maka kemungkinan reaksi negatif yang dimunculkan akan sedikit berbeda.

Pada sisi yang lain, kekakuan berpikir ini sangat bermanfaat bagi individu dengan autisme itu sendiri dan juga orang lain. Misalnya, seorang individu dengan autisme yang sangat menyukai komputer, dan jika kesukaan ini disikapi secara positif oleh orangorang disekitarnya dan dikembangkan dengan baik, maka dia akan menjadi orang yang sangat ahli dalam hal komputer. Kemampuan ini akan bisa dijadikan bekal hidup bagi individu dengan autistik itu sendiri. Dengan keterampilan komputer yang dimiliki, individu dengan autisme bisa bekerja secara mandiri sebagai wiraswata atau self-employed yang tidak harus bertemu dengan orang lain karena kemampuan sosialisasi mereka yang juga menghambat proses berhubungan dengan orang lain.

Ketidakmampuan memprediksi kejadian berikutnya yang mungkin saja terjadi menyebabkan individu dengan autisme membutuhkan kejelasan dan kemudahan dalam menerka kegiatan berikutnya. Untuk tujuan inilah, maka jadwal pembelajaran secara khusus dibuatkan untuk individu dengan autisme, sehingga mereka mengerti dengan jelas kegiatan apa saja yang harus mereka lakukan. Jika dirancang secara benar dan sesuai dengan kebutuhan dari masing-masing individu, maka jadwal-jadwal yang sudah dibuat ini diharapkan akan menjadikan hidup para individu dengan autisme menjadi lebih terorganisasi, mudah memperkirakan aktivitas berikutnya dan berurutan.

Jadwal dibuat untuk tidak hanya perilaku khusus ketika sedang muncul, tetapi juga untuk mengurangi kecemasan dengan cara mengatur anak, mengerti, dan mengantisipasi kegiatan sehari-hari mereka. Jadwal juga membantu individu dengan autisme untuk bergerak secara bebas dan mandiri di dalam kelas tanpa bantuan guru atau orang dewasa yang lain. Individu yang sudah mampu mengikuti jadwal mereka secara mandiri akan terlihat lebih bebas dan bisa beradaptasi dengan lingkungannya. Hal ini sangat penting demi tercapainya kemandirian seorang individu dengan autisme karena banyak anak yang masih dibantu oleh guru maupun orang dewasa lainnya yang kurang bisa mengerti dan memperkirakan kegiatannya, sehingga terlihat kebingungan dan tidak tahu apa yang harus dikerjakannya. 
Bentuk jadwal yang paling sering dipakai adalah jadwal yang ditulis, seperti jadwal sekolah dan buku harian. Untuk individu yang tidak mengalami autisme, jadwal biasanya dibuat untuk waktu satu hari, tetapi untuk individu dengan autisme jadwal haruslah disesuaikan dengan kemampuan mereka. Jadwal untuk individu dengan autisme bisa ditambahkan dengan gambar-gambar atau keterangan tentang aktivitas yang akan dan harus dilakukan sesuai dengan kemampuan individu. Benda-benda tertentu bisa juga digunakan untuk menggantikan tulisan, jika memang individu tersebut hanya mampu mengerti kegiatan yang diwakilkan dengan benda tersebut. Misalnya, jadwal untuk makan diwakilkan dengan piring, sedangkan jadwal untuk mandi diwakilkan dengan gayung.

Individu dengan autisme biasanya kurang mampu mengartikan jadwal tertulis harian secara keseluruhan, maka jadwal yang dibuat juga harus disesuaikan dengan kemampuan anak. Ada jadwal yang dibuat untuk satu hari, ada juga yang dibuat hanya untuk setengah hari sekali waktu. Bahkan, bisa saja jadwal dibuat untuk tiga macam kegiatan dalam waktu yang sama atau hanya untuk satu kegiatan saja dalam satu periode.

Berdasarkan teori dan konsep yang disajikan dalam bagian kajian teori ini, maka hipotesis yang diajukan dalam penelitian ini adalah: "jadwal terstruktur akan mengurangi perilaku maladaptif siswa selama pembelajaran berlangsung".

\section{METODE PENELITIAN}

\section{Jenis Penelitian}

Penelitian ini menggunakan metode kuantitatif dengan jenis penelitian studi kasus yang bertujuan untuk mengubah perilaku maladaptif siswa dengan autisme dengan memberikan perlakuan tertentu secara berulang dalam waktu tertentu. Desain penelitian yang digunakan adalah A-B-A, sehingga pengukuran variabel dilakukan dengan membandingkan tiga kondisi, yaitu 2 X baseline (A1 dan A2) dan sekali intervensi (B).

\section{Tempat dan Waktu Penelitian}

Penelitian ini dilakukan di SLB Tegar Harapan, Sleman, DIY pada bulan Juni sampai dengan November 2012.

\section{Prosedur Penelitian}

\section{a. Sumber Data}

Single Subject Research atau penelitian kasus tunggal sengaja digunakan karena karakteristik yang dimiliki oleh subjek sangat berbeda dengan teman yang lain di sekolah yang sama. Di sekolah ini juga (SLB Tegar Harapan, Mlati, Sleman, DIY), subjek merupakan satu-satunya siswa dengan autisme, sedangkan siswa yang lain adalah penyandang tuna grahita dan tuna daksa. Di antara semua siswa, hanya subjek saja yang tertarik terhadap lebah dan bermainmain dengan lebah.

Dalam penelitian ini, yang menjadi variabel terikat adalah target perilaku yang akan dikurangi, sedangkan variabel bebasnya adalah perlakuan yang diberikan kepada subjek, yaitu jadwal terstruktur yang dipenuhi dengan gambar lebah.

b. Teknik Pengumpulan Data

Teknik pengumpulan data yang digunakan pada penelitian ini adalah pengamatan dengan pencatatan frekuensi dan interval mengenai terjadinya target perilaku yang dimunculkan oleh subjek. Instrumen penelitian yang digunakan adalah lembaran observasi yang diisi pada saat pengamatan ketika perlakuan sedang diberikan. Lembar observasi yang digunakan, berupa pencatatan jumlah perilaku untuk menghindari pembelajaran yang muncul selama kegiatan satu mata pelajaran dan periode setiap perilaku muncul, serta bagaimana reaksi anak dan guru dalam penggunaan jadwal terstruktur selama pembelajaran berlangsung.

\section{c. Teknik Analisis Data}

Data yang didapat dari penelitian ini adalah jumlah perilaku maladaptif yang muncul selama pembelajaran berlangsung pada tahap baseline (A1 dan A2) dan pada saat intervensi dengan menggunakan jadwal terstruktur yang telah dibuat. Teknik analisis data yang digunakan dalam penelitian ini adalah teknik statistik deskriptif yang sederhana (Sunanto, 2005) yang terpusat pada data individu. Analisis data dalam penelitian ini dilakukan dengan menggunakan metode analisis visual dalam kondisi yang meliputi (1) panjang kondisi, (2) estimasi kecenderungan arah, (3) kecenderungan stabilitas, (4) jejak data, (5) level stabilitas dan rentang dan (6) level perubahan.

\section{HASIL DAN PEMBAHASAN}

\section{Hasil Penelitian}

Berdasarkan hasil pengamatan yang dilakukan, selama proses penelitian, untuk mengurangi kekakuan kebiasaan yang berupa perilaku maladaptif yang ditunjukkan selama proses belajar mengajar berlangsung, maka data yang diperoleh akan dideskripsikan sebagai berikut.

Baseline 1 (A1). Pada fase ini atau baseline 1 (A1), peneliti mencatat semua kejadian yang dimunculkan 
oleh subjek tanpa memberikan perlakuan tertentu. Pengumpulan data dilakukan sebanyak lima kali pada setiap hari dan pelajaran yang sama dengan selama 75 menit dengan aktivitas yang berbeda setiap pelajaran. Tahap ini dilaksanakan pada tanggal 16, 23, 30 Juni 2012, serta 7 dan 14 Juli 2012. Perilaku maladaptif yang diamati selama penelitian berlangsung, yaitu menoleh atau melihat ke arah jendela, meninggalkan tempat duduk, dan mengejar lebah pada saat pembelajaran berlangsung. Frekuensi munculnya ketiga perilaku maladaptif tersebut dapat dilihat pada tabel 1 .

Tabel 1. Frekuensi Kemunculan Perilaku Maladaptif pada Fase Baseline Awal (A1)

\begin{tabular}{|l|c|c|c|c|c|}
\hline \multirow{2}{*}{ Perilaku yang diamati } & \multicolumn{5}{|c|}{ Sesi } \\
\cline { 2 - 6 } & 1 & 2 & 3 & 4 & 5 \\
\hline $\begin{array}{l}\text { Perilaku 1 : menoleh atau melihat ke } \\
\text { arah jendela }\end{array}$ & 6 & 5 & 6 & 5 & 5 \\
\hline $\begin{array}{l}\text { Perilaku 2 : meninggalkan tempat } \\
\text { duduk }\end{array}$ & 5 & 5 & 5 & 6 & 5 \\
\hline Perilaku 3 : mengejar lebah & 6 & 5 & 6 & 6 & 6 \\
\hline
\end{tabular}

Berdasarkan data yang ada pada tabel 1, maka kestabilan data akan ditentukan dan dijabarkan sebagai berikut: Perilaku 1, yaitu menoleh atau melihat ke arah jendela selama pembelajaran dikelas berlangsung terjadi sebanyak $6,5,6,5,5$ kali pada masingmasing sesi. Mean data yang diperoleh sebesar 5,4, sehingga data dianggap stabil dan bisa dilanjutkan pada tahap intervensi. Perilaku 2, yaitu meninggalkan tempat duduk selama pembelajaran didalam kelas berlangsung dan kejadian sebanyak 5, 5, 5, 6, 5 kali muncul pada setiap sesi. Dari data yang ada, rata-rata yang diperoleh adalah 5,2, sehingga data dianggap stabil dan bisa dilanjutkan ke tahap intervensi. Perilaku 3, yaitu mengejar lebah selama kegiatan pramuka berlangsung di luar kelas. Ada kejadian sebanyak 6, 5, 6, 6, 6 muncul selama pengamatan berlangsung dan dari data yang ada diperoleh rata-rata sebanyak 5,8 dan persentase stabilitas sebanyak $80 \%$, sehingga bisa dilanjutkan ke tahap intervensi.

Intervensi (B). Berdasarkan data yang diperoleh selama pengamatan pada fase baseline awal, disimpulkan bahwa data dianggap stabil dan bisa dilanjutkan ke tahap berikutnya, yaitu intervensi atau perlakuan. Perlakuan yang diberikan kepada subjek adalah perkenalan dan penggunaan jadwal terstruktur tentang rencana kegiatan selama pembelajaran berlangsung dan hal-hal apa saja yang diharapkan muncul dari subjek. Selama intervensi berlangsung, peneliti menjadi pengamat dan pemberi intervensi pada subjek dan terkadang guru kelas menjadi pemberi intervensi.

Tahap intervensi ini dilakukan sebanyak 8 sesi pada tanggal 21 dan 28 Juli 2012, 1, 8, 15, 22, 29 September 2012 dan 6 oktober 2012 untuk mengukur pengaruh perlakuan yang diberikan kepada subjek. Tabel 2 berikut ini adalah data yang diperoleh selama perlakuan atau intervensi berlangsung.

Tabel 2. Frekuensi Kemunculan Perilaku Maladaptif pada Fase Intervensi (B)

\begin{tabular}{|l|c|c|c|c|c|c|c|c|}
\hline \multirow{2}{*}{ Perilaku yang diamati } & \multicolumn{7}{|c|}{ Sesi } \\
\cline { 2 - 9 } & 1 & 2 & 3 & 4 & 5 & 6 & 7 & 8 \\
\hline $\begin{array}{l}\text { Perilaku 1: menoleh atau } \\
\text { melihat ke arah jendela }\end{array}$ & 4 & 4 & 5 & 4 & 4 & 5 & 4 & 4 \\
\hline $\begin{array}{l}\text { Perilaku 2: meninggalkan } \\
\text { tempat duduk }\end{array}$ & 4 & 4 & 5 & 4 & 4 & 4 & 5 & 4 \\
\hline Perilaku 3: mengejar lebah & 6 & 5 & 5 & 5 & 6 & 4 & 5 & 5 \\
\hline
\end{tabular}

Berdasarkan data yang ada pada tabel 2, maka dapat dijabarkan sebagai berikut. Pertama, perilaku 1 , yaitu menoleh atau melihat ke arah jendela terjadi sebanyak 4, 4, 5, 4, 4, 4, 5, 4 kali. Jika dibandingkan dengan pada fase A1 maka ada kecenderungan untuk berkurang pada perilaku 1, sehingga memungkinkan untuk dilanjutkan pada tahap berikutnya. Kedua, perilaku 2, yaitu meninggalkan tempat duduk dan ada kejadian sebanyak 4, 4, 5, 4, 4, 4, 5, 4 kali pada setiap sesi. Hasil perbandingan dengan fase A1 menunjukkan adanya kecenderungan berkurangnya perilaku 2, sehingga perilaku 2 bisa dilanjutkan ke tahap 3 . Ketiga, perilaku 3, yaitu mengejar lebah selama kegiatan pramuka diluar kelas dan muncul perilaku sebanyak 6, 5, 5, 5, 6, 4, 5, 5 kali pada masing-masing sesi. Hasil ini menunjukkan kecenderungan yang menurun atau berkurang, jika dibandingkan dengan hasil pada fase A1, sehingga perilaku 3 bisa berlanjut ke tahap berikutnya.

Baseline 2 (A2). Selama fase ketiga atau A2, subjek tidak diberikan perlakuan istimewa apapun. Subjek diperlakukan seperti biasanya ketika intervensi tidak diberikan. Fase ini dimaksudkan sebagai fase kontrol terhadap pemberian perlakuan yang sudah dilakukan pada fase kedua. Selama fase ini, data dikumpulkan melalui pengamatan yang dicatat dalam lembaran observasi. Fase ini dilakukan sebanyak 5 kali pada tanggal 13, 20, 27 Oktober 2012 dan 3, 10 November 2012 dan data yang diperoleh disajikan dalam tabel 3.

Tabel 3. Frekuensi Kemunculan Perilaku Maladaptif pada Fase Baseline 2 (A2)

\begin{tabular}{|l|c|c|c|c|c|}
\hline \multirow{2}{*}{ Perilaku yang diamati } & \multicolumn{5}{|c|}{ Sesi } \\
\cline { 2 - 7 } & 1 & 2 & 3 & 4 & 5 \\
\hline $\begin{array}{l}\text { Perilaku 1: menoleh atau melihat ke arah } \\
\text { jendela }\end{array}$ & 3 & 3 & 2 & 3 & 3 \\
\hline Perilaku 2: meninggalkan tempat duduk & 2 & 3 & 2 & 2 & 3 \\
\hline Perilaku 3: mengejar lebah & 3 & 2 & 3 & 3 & 3 \\
\hline
\end{tabular}


Data pada tabel 3, dapat dijelaskan bahwa jumlah kejadian perilaku 1 pada fase 3, yaitu 3, 3, 2,3, 3 kali pada setiap sesi. Sedangkan jumlah kejadian perilaku 2 yang dimunculkan pada setiap sesi dalam fase kedua, yaitu 2, 3, 2, 2, 3. Jumlah kejadian perilaku 3 pada fase 3 , yaitu 3, 2, 3, 3, 3 kali pada masing-masing sesi. Perbandingan perolehan data pada masing-masing fase dapat dilihat pada tabel 4 .

Tabel 4. Frekuensi Kemunculan Perilaku Maladaptif pada Fase A1, B dan A2

\begin{tabular}{|c|c|c|c|c|}
\hline Fase & Sesi & Perilaku 1 & Perilaku 2 & Perilaku 3 \\
\hline \multirow{4}{*}{ A1 } & 1 & 6 & 5 & 6 \\
\cline { 2 - 5 } & 2 & 5 & 5 & 5 \\
\cline { 2 - 5 } & 3 & 6 & 5 & 6 \\
\cline { 2 - 5 } & 4 & 5 & 6 & 6 \\
\cline { 2 - 5 } & 5 & 5 & 5 & 6 \\
\hline \multirow{5}{*}{ B } & 6 & 4 & 4 & 6 \\
\cline { 2 - 5 } & 7 & 4 & 4 & 5 \\
\cline { 2 - 5 } & 8 & 5 & 5 & 5 \\
\cline { 2 - 5 } & 9 & 4 & 4 & 5 \\
\cline { 2 - 5 } & 10 & 4 & 4 & 6 \\
\cline { 2 - 5 } & 11 & 5 & 4 & 4 \\
\cline { 2 - 5 } & 12 & 4 & 5 & 5 \\
\hline A2 & 13 & 4 & 4 & 5 \\
\hline \multirow{3}{*}{ A2 } & 14 & 3 & 2 & 3 \\
\cline { 2 - 5 } & 15 & 3 & 3 & 2 \\
\cline { 2 - 5 } & 16 & 2 & 2 & 3 \\
\cline { 2 - 5 } & 17 & 3 & 2 & 3 \\
\hline
\end{tabular}

Berdasarkan tabel 4, dapat kita lihat dengan jelas bahwa ada kecenderungan penurunan munculnya perilaku pada setiap fase yang ada.

\section{Pembahasan}

Analisis data dalam penelitian ini menggunakan analisis visual dalam kondisi dengan cara mencari (1) panjang kondisi, (2) estimasi kecenderungan arah, (3) kecenderungan stabilitas, (4) jejak data, (5) level stabilitas dan rentang, serta (6) level perubahan.

a. Baseline 1 (A1)

Tabel 5. Rangkuman Hasil Analisis Visual dalam Kondisi pada Perilaku 1

\begin{tabular}{|c|l|c|c|c|}
\hline No & \multicolumn{1}{|c|}{ Kondisi } & A1 & B & A2 \\
\hline 1. & Panjang Kondisi & 5 & 8 & 5 \\
\hline 2. & $\begin{array}{l}\text { Kecenderungan } \\
\text { Arah }\end{array}$ & - & & \\
\hline 3. & $\begin{array}{l}\text { Kecenderungan } \\
\text { Stabilitas }\end{array}$ & $\begin{array}{c}100 \% \\
(\text { stabil })\end{array}$ & $\begin{array}{c}100 \% \\
(\text { stabil })\end{array}$ & $\begin{array}{c}80 \% \\
\text { (variabel) }\end{array}$ \\
\hline 4. & Jejak Data & - & & \\
\hline 5. & Level Stabilitas dan & $\begin{array}{c}\text { Stabil } \\
5-6\end{array}$ & $\begin{array}{c}\text { Stabil } \\
4-5\end{array}$ & $\begin{array}{c}\text { Variabel } \\
2-3\end{array}$ \\
\hline 6. & Perubahan Level & $6-5=1$ & $4-4=0$ & $3-3=0$ \\
\hline
\end{tabular}

Berdasarkan rangkuman hasil analisis visual dalam kondisi yang disajikan pada tabel 5, maka dapat diketahui bahwa pada fase baseline 1 (A1) kecenderungan arah data menunjukkan penurunan yang tidak terlalu tajam pada mean level 5,4. Pada saat intervensi atau B perilaku menunjukkan kecenderungan yang menaik dan pada fase A2 perilaku 1 menunjukkan kecenderungan yang sedikit menurun.

b. Intervensi (B)

Tabel 6. Rangkuman Hasil Analisis Visual dalam Kondisi pada Perilaku 2

\begin{tabular}{|c|c|c|c|c|}
\hline No & Kondisi & $\mathrm{A} 1$ & B & A2 \\
\hline 1. & Panjang Kondisi & 5 & 8 & 5 \\
\hline 2. & $\begin{array}{l}\text { Kecenderungan } \\
\text { Arah }\end{array}$ & & & \\
\hline 3. & $\begin{array}{l}\text { Kecenderungan } \\
\text { Stabilitas }\end{array}$ & $\begin{array}{l}100 \% \\
\text { (stabil) }\end{array}$ & $\begin{array}{l}100 \% \\
\text { (stabil) }\end{array}$ & $\begin{array}{l}100 \% \\
\text { (stabil) }\end{array}$ \\
\hline 4. & Jejak Data & & & \\
\hline 5. & $\begin{array}{l}\text { Level Stabilitas dan } \\
\text { Rentang }\end{array}$ & $\begin{array}{l}\text { Stabil } \\
5-6\end{array}$ & $\begin{array}{l}\text { Stabil } \\
4-5\end{array}$ & $\begin{array}{l}\text { Variabel } \\
2-3\end{array}$ \\
\hline 6. & Perubahan Level & $6-5=1$ & $4-4=0$ & $3-3=0$ \\
\hline
\end{tabular}

Berdasarkan tabel 6, dapat kita lihat bahwa perilaku maladaptif 2 yang akan dikurangi pada fase baseline awal menunjukkan kecenderungan yang meningkat pada mean level 5,2. Sedangkan pada fase intervensi dengan mean level yang menurun dibandingkan tahap baseline awal, yaitu 4,25, menunjukkan kecenderungan yang mendatar. Sedangkan pada mean level 2,4 pada fase baseline yang kedua menunjukkan kecenderungan yang menurun.

Baseline 2 (A2). Berdasarkan analisis visual dalam kondisi yang telah dilakukan, maka kesimpulan yang didapatkan disajikan dalam tabel 7.

Tabel 7. Rangkuman Hasil Analisis Visual dalam Kondisi pada Perilaku 3

\begin{tabular}{|c|l|c|c|c|}
\hline No & \multicolumn{1}{|c|}{ Kondisi } & A1 & B & A2 \\
\hline 1. & Panjang Kondisi & 5 & 8 & 5 \\
\hline 2. & $\begin{array}{l}\text { Kecenderungan } \\
\text { Arah }\end{array}$ & & & \\
\hline 3. & $\begin{array}{l}\text { Kecenderungan } \\
\text { Stabilitas }\end{array}$ & $\begin{array}{c}100 \% \\
(\text { stabil) }\end{array}$ & $\begin{array}{c}87,5 \% \\
(\text { stabil })\end{array}$ & $\begin{array}{c}80 \% \\
\text { (variabel) }\end{array}$ \\
\hline 4. & Jejak Data & & & \\
\hline 5. & $\begin{array}{l}\text { Level Stabilitas dan } \\
\text { Rentang }\end{array}$ & $\begin{array}{c}\text { Stabil } \\
5-6\end{array}$ & $\begin{array}{c}\text { Stabil } \\
4-6\end{array}$ & $\begin{array}{c}\text { Variabel } \\
2-3\end{array}$ \\
\hline 6. & Perubahan Level & $6-6=0$ & $6-5=1$ & $3-3=0$ \\
\hline
\end{tabular}

Dari tabel 7 di atas, dapat kita lihat bahwa pada fase baseline awal (A1) dengan mean level 5,8 ada kecenderungan perilaku 3 untuk menaik. Pada saat intervensi (B) dengan mean level 5,125 kecenderungan perilaku 3 juga menurun sedangkan pada fase base- 
line 2 dengan mean level sebesar 2,8, kecenderungan perilaku 3 adalah meningkat.

Penelitian ini dikatakan berhasil, jika perilaku maladaptif yang dimunculkan oleh subjek mengalami penurunan frekuensi yang terlihat dengan jelas pada saat-saat akhir pemberian perlakuan (B) yang dibandingkan dengan sebelum perlakuan diberikan (A1). Dari data yang diperoleh selama masa baseline awal, intervensi dan baseline kedua, menunjukkan, bahwa perilaku maladaptif siswa yang dimunculkan pada saat kegiatan pembelajaran di dalamdan luar kelas (Pramuka) menunjukkan kecenderungan yang berkurang meskipun tidak sangat signifikan. Berdasarkan analisis data yang telah dilakukan, maka penggunaan jadwal terstruktur untuk mengurangi kekakuan kebiasaan dalam hal ini adalah kebiasaan subjek untuk melihat ke arah jendela, berdiri dari tempat duduk, dan mengejar lebah bisa digunakan sebagai salah satu alternatif cara untuk mengurangi perilaku maladaptif yang dimunculkan oleh subjek yang sangat mengganggu proses pembelajaran.

\section{PENUTUP}

\section{Kesimpulan}

Perilaku maladaptif yang ingin dikurangi atau bahkan dihilangkan dalam penelitian ini ada tiga macam, yaitu perilaku menoleh atau melihat ke arah jendela untuk melihat lebah, meninggalkan kursi untuk mengejar lebah dan mengejar lebah selama pembelajaran diluar kelas berlangsung. Frekuensi kejadian munculnya ketiga perilaku maladaptif yang dimunculkan selama penelitian berlangsung menunjukkan kecenderungan yang mengurang.

Perilaku 1, pada saat baseline awal rata-rata munculnya perilaku 1 adalah sebanyak 5 kali sedangkan pada saat intervensi ada kecenderungan untuk berkurang dari 5 menjadi 4 sedangkan pada fase baseline 2, frekuensi perilaku 1 menurun menjadi 4. Pada perilaku 2, saat baseline awal, frekuensi kejadiannya adalah 5 sedangkan pada saat intervensi berkurang menjadi 4 dan pada fase baseline 2 frekuensinya semakin berkurang menjadi 3. Perilaku yang terakhir yaitu mengejar lebah frekuensinya pada saat baseline awal adalah 6 sedangkan pada saat intervensi rata- rata frekuensinya menurun menjadi 5 dan setelah intervensi kembali menurun menjadi 3.

Berdasarkan data yang ada dan analisis yang telah dilakukan, maka dapat disimpulkan bahwa jadwal terstruktur dapat digunakan sebagai salah satu alternatif untuk mengurangi kekakuan kebiasaan pada anak dengan autisme.

\section{Saran}

Berdasarkan kesimpulan yang sudah dibuat, maka peneliti memberikan beberapa saran bagi beberapa pihak yang berhubungan dengan pendidikan anak dengan autisme terutama guru yaitu bahwa jadwal terstruktur bisa digunakan dan diterapkan untuk mengurangi frekuensi kemunculan perilaku maladaptif yang mengganggu proses pembelajaran. Sedangkan untuk peneliti lain, penelitian ini bisa dilakukan pada anak dengan autisme yang lain dengan karakteristik yang berbeda sehingga akan dapat diketahui efektifitas penggunaan jadwal terstruktur untuk mengurangi perilaku maladaptif pada populasi yang lebih luas.

\section{DAFTAR PUSTAKA}

Fitzpatrick, M.(2004). MMR and autism: What parents need to know. London: Routledge

Ginanjar, A.S. (2007). Memahami spektrum autistik secara holistik (disertasi). Program Pascasarjana Fakultas Psikologi Universitas Indonesia

Mesibov, G. dan Howley, M. (2003). Accessing the curriculum for pupils with autistic spectrum disorders: Using the TEACCH programme to help inclusion. London: David Fulton

Stuart, L., et.al. (2004). Autistic spectrum disorders: practical strategies for teachers and other professional. Northumberland county council communication support service. London: David Fulton

TEACCH. (2006). TEACCH classroom training (handbook). Charlotte: Charlotte TEACCH Center

Volkmar, F., Paul R., Klin A., \& Cohen, D. (Eds) (2005). Handbook of autism and pervasive developmental disorders. Third edition volume 1: Diagnosis, development, neurobiology, and behavior. Hoboken: John Wiley \& Sons 